Research Article

\title{
EXPECATION GAP IN SURABAYA: THE ASSESSMENT BETWEEN AUDITORS WITH AUDIT REPORT USERS
}

\author{
Danny Wibowo* \\ Sekolah Tinggi Ilmu Ekonomi Indonesia Surabaya, Indonesia
}

Article history:

Submission 01 February 2021

Revised 26 May 2021

Accepted 21 June 2021

*Corresponding author:

E-mail:

dannywbowo@stiesia.ac.id

\begin{abstract}
Expectation gaps always occur in companies where there is a difference between what public accountants (auditors) believe to be their responsibilities and what users of financial statements want. Thus this study discusses the expectation gap which aims to determine the performance of auditors in performing any audit work, to know the reactions of audit report users when reading the audit results and to find out the process between auditors and audit report users when experiencing an expectation gap. This assessment uses qualitative data type. Sources of data used are through observation and interviews. This research uses descriptive research and data analysis used is descriptive qualitative analysis. In this study, there is a conclusion that there are differences in expectations between auditors and auditees. Factors that trigger differences in expectations include; audit education both on the auditor and the auditee side, the standards owned by auditor, the auditor's performance and the auditor's experience and the auditee's attitude.
\end{abstract}

Keywords: Expectation gap, Auditor, Audit report users

\section{Introduction}

Some of the characteristics of financial reports include: relevant, understandable, comparable and reliable (Financial Accounting Standards, 2018). These characteristics make financial reports useful for users of financial statements for decision making. The financial report is a special tool used in evaluating company performance, performance of operating activities, investment activities and financing activities. In presenting financial reports is one form of implementation of public financial management accountability. If the decision is made without being based on unreliable finan- cial statements, it can lead to different interpretations between users of financial statements, so that it can be misleading and result in inappropriate decisions taken (Widosari \& Rahadja, 2012).

Audit activities are needed to resolve any differences in interests between users of financial statements and management. While the purpose of the audit is to express an opinion on the fairness in all material matters, financial position, and results of operations and cash flow in accordance with generally accepted accounting principles (Halim, 2015). While the roles and responsibilities of auditors are

How to cite:

Wibowo, D. (2021). Expectation gap in Surabaya: the assessment between auditors with audit report users. Indonesian Journal of Social Science Research, 2(1), 1 - 9. doi: 10.11594/ijssr.02.01.01 
regulated in the Public Accountants Professional Standards (SPAP) established by the Indonesian Institute of Accountants (IAI) (Indonesian Institute of Certified Public Accountants, 2011). The auditors' responsibilities include finding misstatements caused by negligence or fraud, maintaining independent attitude, and the survival of customers in the future. In practice, these standards make a difference for users who do not understand the role of public accountants in interpreting audit reports (Herman and Eliza, 2018).

Thus the users of financial statement information from external parties have different objectives depending on their needs. Internal users include managers and owners while external users are business. For this reason, the financial information presented in the financial statements must be understandable, reliable, objective and acceptable to users as a useful source of information.

The perceptions of users of the audited financial statements regarding the role of the auditor may differ from the role of the actual auditor. The difference between what the public or users of financial statements expect from the auditors and what the auditor actually does creates an expectation gap. The audit expectation gap was first disclosed by Liggio in the journal Indrijawati (2013) which states that the expectation gap arises because of differences in perceptions between independent accountants and users of financial statements regarding the level of performance expected of the accounting profession.

It can be concluded that this expectation gap occurs due to a lack of communication and understanding from the parties, causing differences in perceptions and opinions. But this can be overcome with awareness and responsibility from each party. This needs to be done in order to facilitate effective performance and efficiency which in the end, the reflection of understanding and attitudes shown by the parties can mutually understand, obey and obey professional rules, legal rules and enforce the professional morality.

The profession is always in touch with legal aspects which also indicates the importance of legal awareness for an auditor. Experts such as
Ganuza and Gomez (2007) reveal the importance of adherence to professional standards, in their writing that it is crucial for the role of gatekeepers such as auditors, lawyers and stock analysis. The issue of independence is at the top of the agenda for an auditor. Furthermore, the design of professional standards that can control auditors should be accepted as the main deterrent to reducing deviant behavior. Recognizing this means that compliance with professional standards for auditors is a must as proof of their responsibility to carry out their profession.

Several studies on the Expectation Gap by Sari and Widyastuti (2018), Herman and Eliza (2018), Prayudi, et al., (2018), Munidewi and Pertiwi (2016), Mirdah, et al., (2015), and Yandi (2015) shows that there is a difference between what public accountants (auditors) believe to be their responsibilities and what users of financial statements want.

Researches on the expectation gap are mostly carried out in the private sector, so it seems that research in the public sector has received less attention from both academics and professionals. In this study, the authors chose to conduct a study entitled "Expectation Gap in Surabaya: An Assessment Between Auditors and Audit Report Users".

Based on the background that has been stated above, the problem formulations to be discussed are as follows:

a. How do auditors perform audit work?

b. How do audit report users react when reading the audit results?

c. What happens between auditors and users of audit reports when they experience an expectation gap?

\section{Research Purposes}

a. This is to determine the performance of auditors in performing audit work

b. This is to determine the reaction of audit report users when reading the audit results.

c. This is to determine the process between the auditor and the user of the audit report when they experience an expectation gap. 


\section{Literature Review Attitude and Behavior Theory}

The theory of attitudes and behavior (Theory of Attitudes and Behavior) developed by Trinandis (1971), states that a person's behavior is determined by attitudes related to what people want to do (attitudes) and consists of beliefs about the consequences of doing behavior, social rules related to what they used to do (habit). Jazen (1985) in Arumsari (2014) states that attitudes can be learned, attitudes define our predisposition against any aspects that occur in the world, attitudes provide a feeling base for the relationship between our personal and other people, and attitudes are evaluative statements, both beneficial or unfavorable about objects, people, or events. Attitude is an individual tendency to think, feel or act positively or negatively towards objects in our environment. Fishbein and Ajzen (1975) in their article entitled Understanding attitudes and predicting social Behaviors say that the main determining factor is personality. How an individual assesses whether a behavior is positive or negative before taking an action. Behavior would be impossible if the situation were not possible. Sari and Ramantha (2015) explain that a person's behavior is caused by 18 personal factors. Personal factors are factors that come from within a person. When associated with this research, personal factors consist of the attitude of the auditor's experience in auditing financial statements and the internal locus of control that the auditor has on the professional auditor's skepticism. Thus, the theory of attitudes and behavior is able to influence auditors to manage their personal factors so that they affect the personality of the auditor in being honest, thorough, not taking sides with a particular interest, thinking rationally, surviving even in a state of depression, behaving ethically by always heeding professional norms, standards audits that have been established and the applicable moral norms that will later influence the auditor in providing an opinion on the financial statements he/she audits.

\section{Definition of Expectation Gap}

According to the Cohen Commission Report, it explains that the Expectation Gap occurs due to the phenomenon of differences in perceptions between users of financial statements and auditors who are the responsibility of the auditors (Guy \& Sullivan, 1988). Jusuf (1999) states that society perceives business failure as an audit failure. Jusuf (1999) states that people perceive business failure as an audit failure. Hartadi et al., (2001) in their research explained that the Expectation Gap is the difference in the role of public accountants in financial reporting and the meaning of audit reports for users. The community considers that the accountant's report is a guarantee to validate the quality of a company (Mirdah et al., 2015). This understanding is also illustrated by Regar (2007) that the public considers the accountant's report to provide recognition (certification) regarding the success of a company. The expectation of the users of financial statements against the auditor triggers the expectation gap. The audit expectation gap is a gap between the responsibilities expected by society against auditors (Porter et al., 2012). While the definition of the audit expectation gap according to Masoud (2017) is the gap in public expectations of the auditor performance and the actual performance shown by auditors. Based on the above understanding, it can be concluded that the expectation gap is a gap that arises due to differences between the expectations of the public using financial statements and the audit reports produced by auditors.

Several terms related to the expectation gap include: (a) audit assurance; (b) audit reporting; and (c) audit independence.

Audit Assurance, the auditor is expected to be able to provide adequate assurance on the fairness of the financial statements being audited or a guarantee for the financial statements being audited. Auditors are also expected to be able to give a signal due the inefficiencies that occur in client companies. (Munidewi \& Pertiwi, 2016).

Audit Reporting, giving a fair opinion without exception should be granted to the company being audited, regardless of financial scandals. Investors and bankers want auditors to be accountable not only to the management of the company being audited, but also to third parties, when financial transactions are increasingly complex and involve investors (Sari \& Widyastuti, 2018). 
Audit Independence, the existence of intense business competition makes professional organizations worry that auditors will lose their independence (Sari \& Widyastuti, 2018). Competition between public accounting firms makes them reduce audit fees, so that auditors do not carry out several standard procedures that must be fulfilled (Sari \& Widyastuti, 2018).

\section{Efforts to Reduce the Expectation Gap}

In general, so as to reduce perceptions and opinions or can be called the expectation gap in general, it can be pursued by:

Efforts through an expanded or modified audit report, namely by changing the format or words contained in the audit report. Efforts through education, with the system and culture of the community using financial statements.

Through improving audit quality, by requiring auditors to carry out higher audit quality. This audit quality improvement can be pursued in various ways or systems which in essence lead to audit quality.

\section{User of Audit Report}

The audit report is very important in an audit process because the audit report informs users of information about what the auditor did and what conclusions he obtained. The audit report contains an audit opinion that assesses the fairness of the company's financial statements. One of the benefits of an audit opinion for users of financial statements can be used as a consideration for investment decisions by investors and credit extension by creditors and other decisions from other users of financial statements.

Users of audited financial statements, both external and internal parties, are expected to understand and understand the information presented in the financial statements in order to make it easier to translate what is contained in the financial statements as well to carry out analyzes related to company performance, if users of the report company finances do not understand, so users tend not to use the company's financial information optimally. The use of company financial statement information is related to the assessment of users of the com- pany's financial statements against to the accountability and transparency of each financial report presented by the company. By doing so, financial statement accountability can be used by users of financial statements as a consideration for investment decision making by investors and credit extension by creditors and other decisions from other users of financial statements.

Syahyunan (2015) the purpose of investor in investing is to get profit. Investments that are obtained by investors are investment alternatives that are expected to provide the highest rate of return. However, in reality, the rate of profit actually obtained by investors (actual return) is not always the same as the rate of return that was previously expected (expected return). In other words, investors who invest may deal with the risk of the possibility of deviating the actual rate of return from the expected rate of return.

\section{Accountability of the Professional Auditor}

Public Accountants Professional Standards (SPAP) have regulated the roles and responsibilities of auditors, including detecting and reporting fraud, errors and irregularities (SPAP section 316); as well as maintaining an independent attitude (SPAP section 220). An auditor is expected to be able to produce quality audits (Lestari, et al. 2019). Audit quality measures include four categories, namely: input, process, results, and context (Tandiontong, 2016: 80). Audit quality is also related to due professional care. Careful and thorough professional skills enable auditors to gain confidence that the financial statements are free from material misstatement (Faturachman and Nugraha, 2015). Audit quality also requires the competence of an auditor that is obtained through education and experience, so that they can carry out audits objectively, carefully and thoroughly (Lestari, et al. 2019).

\section{Method \\ Types of research}

The research method according to Sugiyono (2012) is a scientific way to obtain valid data with the aim that certain knowledge can be discovered, developed, and proven, so 
that in turn it can be used to understand, solve and anticipate problems.

So that the type of research used in this research is descriptive research. Descriptive research is a research that it is intended to collect information about the status of an existing symptom, namely the state of the symptoms according to what it was at the time of the research that was conducted by Arikunto (2013).

With this method the writer intends to collect historical information and observe carefully about certain aspects related to the problem being researched by the writer so that it will obtain data that can support the preparation of research reports.

\section{Place and Time of Research}

The research plan is carried out in Surabaya and the research will be carried out from August to December 2020.

\section{Data Collection Method}

This study uses qualitative data. Sources of data used are through observation and interviews. Informants were determined using a quota procedure, which is often regarded as a kind of purposive procedure. In the quota procedure, the selected informants reflect the appropriate proportion between the number of auditors and the number of financial report users who have insight into the topic of the expectation gap (Bungin, 2011). The observations used are group observations, namely observations made in groups including auditors and users of financial statements along with researchers who are observing the expectation gap (Bungin, 2011). The interview method used is in-depth interviews, namely questions and answers with or without using interview guidelines, where both master and understand about the expectation gap which is the object of research (Bungin, 2011).

\section{Data analysis method}

The data analysis is exercised using qualitative descriptive analysis method, where the data is collected, then understood and analyzed so that it can provide a clear picture of the suitability of how to overcome the Expectation Gap in financial report auditing activities with the
Public Accountant Professional Standards issued by the Indonesian Public Accountants Association. Thus the authors use performance analysis, namely individual experiences and institutional behavior. (Bungin, 2011). Using a case study approach (Bungin, 2011). A case study is one of the strategies and methods of qualitative data analysis which in this case emphasizes the behavior of auditors and users of financial reports regarding the expectation gap. The type of case study used in this research is an observational case study (Bungin, 2011). There are five components in the design of this research case study, namely: (1) research questions; (2) the proportion of research according to the scope of the research; (3) research analysis units; (4) data-related logic; and (5) criteria for interpreting the findings (Bungin, 2011).

\section{Results and Discussion \\ General Description of The Subject}

The research was done by conducting interviews with auditors and users of audit reports (users of financial reports) separately, both in time and place. Because in a pandemic condition, interviews were conducted using an online meeting application (zoom, WhatsApp) directly between the researcher and the respondent. The next process is after the researcher obtains answers from each of the research respondents and then concludes the answers from the respondents then they are sent back to the respondents for approval (all done separately).

In the first session, the researcher conducted interviews with a group of auditors from 5 public accounting firms in Surabaya who has position as team leader and / or project manager. Meanwhile, before conducting the focus group discussion, the researchers has already conducted an in-depth interview with the participants. Then the next interview is to the auditee, which in this case is the user of the financial statements by taking a sample of 5 auditees from different companies, while the selected sample is the head of the finance / accounting department in each company.

The substance statement from the results of the interview with the auditor is as follows: 
Auditor 1: "yes, we hope that as auditors we are provided with sufficient data in conducting audits against the financial statements so that our opinion upon the client's financial statements is accurate, then our intention is that auditors to do the audit of financial statements are to provide an overview to the auditee that everything related to the financial statement information that we audited is according to the type of opinion which we express into such financial statements, for example if our report is reasonable without any exception, then by doing so we assure the auditees that their financial statements are free from any material errors. Another example is when our opinion is reasonable by exception, we assure the auditees that their financial statements are generally in good condition, meaning there are no errors, but there are still some things that needed to be noted. Then upon the audit report, we hope that it can be used as well as possible, made as a component in company decision making. It should also be underlined that we also work in accordance with our duties and responsibilities in a professional manner based on the adopted procedures and comply with the rules", it's just that these auditees are sometimes lacking in this regard.

Lee et al., (2007) in the audit expectation gap: an empirical study in Malaysia is in line with the respondent's statement above that auditors and audit beneficiaries place far higher expectations on the auditor's duties when compared to what auditors consider their duties.

Auditor 2: "Financial reports are an important instrument in supporting management to make decisions. So I, as an auditor, hope that users of audit results reports can use our audit report as material for future evaluation, so that errors for decision making that may occur can be minimized. Therefore, during the audit, please fully support the auditor, especially in terms of providing data," and sometimes what we feel strange from the auditee is that they doubt or expect something that is beyond our expectations, as if they doubt our credibility as an auditor, well things like that we are a bit sorry, why? yes because we are educated and experienced personnel.
This was also stated by Yasemin et al., (2015) who found that there was a fairness gap and a performance gap between auditors and audit report users. Independent audit education and experience are two main factors that can significantly reduce such fairness gap.

Auditor 3: "We do really want to be fully supported in the audit process such as the availability of information and management transparency because it is to expedite the procedures we carry out in order to know the level of quality of our clients' financial statements, and of course in conducting audits we base this financial statement audit procedure on applicable audit standards, therefore our hope for clients is that they can accept and use our audit report (opinion) as evaluation material so that decisions made by management (auditee) in the future are not wrong. "

Auditor 4: "I hope the auditee should be able to cooperate with us the auditors because in essence of the audit report it describes the company's financial situation, I hope that the audit report that has been issued with all of its opinions are able to give a good impact on the company's sustainability, this means, if the opinion is reasonable without exception, the company should be able to defend it because of an unqualified opinion on the report because this matter could be an indicator of a healthy company."

Auditor 5: "Our goal in conducting audits in financial statements is so that client companies are sure of their financial statement information. Whether in reasonable conditions or otherwise, well, besides that, of course, in providing our opinion on our financial statements, we are sure to go through applicable standards and procedures, starting from that understanding, our hope as an auditor is that in the audit process we are assisted by providing sufficient and accurate data, so that our audit report can be used as well as possible, especially to support decision making "

From the auditors' statements 3, 4 and 5, it can be concluded that the auditors need the cooperation of the auditee to obtain valid and 
sufficient data in order to be able to issue an opinion on the financial statements accurately, with such auditor expectations, then on the other hand, that so far according to the experience of auditors 3,4 and 5, the auditees have not been able to understand the duties and roles of auditors, this is in accordance with research conducted by Okafor \& Otalor (2013) which found that the public have ignored the duties of auditors and the lacks of this knowledge shall become his responsibility.

The substance statement from the results of interviews with auditees / users of financial statements is as follows:

Auditee 1: "Our hope for auditors is that they can provide positive input to our financial records, not looking for mistakes, but more inclined to correct these mistakes, because most of auditors prefer to find our mistakes, as the financial report makers. We fully support them with data, but why do sometimes opinions on financial reports always do not match with our expectations. Yes, not all auditors but the majority are do like that. Then besides that I also hope that the auditors can explain their examination procedures, this is why in order they can work more professional and we also know that what will be done later when the audit is not out of procedure "

This is in accordance with research by Fadzly and Ahmad (2004; Lee et al., 2007) which found that Expectation GAP in Malaysia is due to lack of standards and lack of performance from auditors.

Auditee 2: "I have given my best efforts to provide the data provided by the auditors, but why are the opinions not in accordance with our expectations, even though if we pay close attention, none of our records are material. I think this auditor is looking for more of our mistakes without taking into account or thinking about other things that might be our rationality to record this way, such as in the financial statements. I sometimes wonder whether those auditors assigned to audit us are really experienced or not, because I have seen several times that they are very unprofessional "

This is in line with the findings of Yasemin et al., (2015). The results imply that the more experienced participants, the fewer unreasonable expectations in terms of auditor responsibilities. Likewise, an increase in the level of audit education will reduce the expectation gap.

Auditee 3: "The auditor asks for various kinds of data, even from some of these requests it is impossible for us to fulfill and what we think is a very trivial matter, I hope the auditor can cooperate with the auditee, not because trivial things can affect the audit report."

Research by Ali et al., (2015) states that one of the things that greatly influences the existence of an audit gap is the role of auditors who respect clients.

Auditee 4: "Actually, what I want to know about the auditors is how their paperwork is, they are experienced people, but why do they always ask for a lot of requests for this check, but when they are asked they almost always answer that this is the procedure we have to do. Then for the audit report, please don't be so strict because all of that can be discussed, not only according to their own will"

This was also stated by Lee et al., (2010) who stated that the lack of auditor performance in Thailand triggered the expectation GAP.

Auditee 5: "What I expect the most from auditors is that they can also submit their examination procedures then the calculation formulation to determine the opinion, because until now there has not been any and I have only been given an explanation of the auditors' examination procedures, they only asked for this data, causing us to become wondering what their actual examination procedure was actually like."

Auditee 5's statement above is in line with J.S. Kumari, A.R. Ajward, D.B.P.H. Dissabandara at Vidyodaya Journal of Management who found that there was a gap in audit expectations in the Sri Lankan context; and that audit education has the effect of reducing this gap. However, further analysis showed that only advanced auditing courses were successful in minimizing the expectation gap (especially in reducing the gap of unreasonable expectations) compared to those who had taken the basic audit course. 


\section{Conclusions and Suggestions Conclusions}

From the statements of the auditors and auditees above, it can be concluded that there are differences in expectations between auditors and auditees. Factors that trigger differences in expectations include; audit education both on the auditors' and auditees' side, the auditors' standards, the auditor's performance and the auditor's experience and the auditee's attitude.

\section{Suggestions}

Advanced auditing education is needed to reduce the expectation gap between auditors and auditees, then the control of an accounting firm in auditing activities is needed, such as setting adequate standards and continuing education for auditors. This study has the first limitation in terms of the scope of the study, that the research was only conducted at public accounting firms in the city of Surabaya. Therefore, the researcher expects further researchers to expand the scope and sample of the study. Then with regard to users of financial statements here, the researcher only takes a sample from the auditee (management) who handles financial reports, for further research the researcher hopes that the research will also be carried out on all stakeholders in the entity.

\section{References}

Ali. F., A. Muhammad., R. Hasan dan N. S. A. Ahmed. (2015), An Empirical Investigation of the Audit Expectation Gap in Pakistan. International Journal of African and Asian Studies. Vol. 11.

Arikunto, S. (2013), Prosedur Penelitian Suatu Pendekatan Praktik. Jakarta: Rineka Cipta.

Arumsari, A.L. (2014), Pengaruh Profesionalisme Auditor, Independensi, Auditor, Etika Profesi,Budaya Organisasi, dan Gaya Kepemimpinan Terhadap Kinerja Auditor Pada Kantor Akuntan Publik di Bali. Tesis. Denpasar: Universitas Udayana.

Bungin, B. (2011), Penelitian Kualitatif, Komunikasi, Ekonomi, Kebijakan Publik, dan Ilmu Sosial Lainnya. Second Edition. Kencana Prenada Media Group. Jakarta.

Fishbein, M and I. Ajzen. (1975), Belief, Attitude, Intention and Behavior: an Introduction to Theory and Research. Reading, MA: Addison-Wesley.

Faturachman, T.A., and A. Nugraha. (2015). Pengaruh Due Professional Care Terhadap Kualitas Audit Pada
Kantor Akuntan Publik Di Kota Bandung. Jurnal Riset Akuntansi dan Keuangan Program Studi Akuntansi Fakultas Pendidikan Ekonomi dan Bisnis Universitas Pendidikan Indonesia. 3(1): 562-571.

Ganuza, J. J and F. Gomez. (2007), Should we trust the gatekeepers? Auditors' and Lawyers' Liability for Clients Misconduct. International Review of Law and Economics

Guy D.M. and J.D. Sullivan. (1988), The Expectation Auditing Standards. The Journal of Accountancy. April. 38(3): 36-46.

Halim, A. (2015). Auditing (Dasar-dasar Audit Laporan Keuangan). Jilid 1. Edisi Kelima. UPP STIM YKPN. Yogyakarta.

(2001), Manajemen Keuangan Daerah. UPP-AMP. Yogyakarta.

Hartadi, B. (2004), Auditing Suatu Pendekatan Komprehensif Per Pos dan Per Siklus. BPFE. Yogyakarta.

T.B.A. Bambang, dan B. Tarigan. (2001), Auditing: Suatu Pendekatan Komprehensif Per Pos dan Per Siklus. Edisi Pertama. Mudaya. Yogyakarta.

Herman, L.A., dan S. Eliza. (2018) Persepsi Mahasiswa, Auditor dan Pemakai Laporan Keuangan Terhadap Peran Serta Tanggung Jawab Auditor (Studi Empiris Mengenai Expectation Gap). Jurnal Benefita. 3(3): 303-314.

Ikatan Akuntan Indonesia. (2018), Standar Akuntansi Keuangan. Salemba Empat. Jakarta.

Indrijawati, A. (2013), Kesenjangan Harapan Audit Pada Sektor Publik (Studi Empiris di Provinsi Sulawesi Selatan). Disertasi Program Doktor Ilmu Ekonomi Fakultas Ekonomi dan Bisnis Universitas Hasanuddin. Makassar.

Institut Akuntan Publik Indonesia. (2011), Standar Profesional Akuntan Publik. Salemba Empat. Jakarta.

Jusuf, A.A. 1999. Persepsi Ekspektasi. Media Akuntansi. 33(6): 46.

Köse. Y., S. Erdogan, M. F. Dergisi. (2015), The Audit Expectations Gap in Turkey. Muhasebe ve Finansman Dergisi-The Journal of Accounting and Finance. 193214.

Kumari J.S., A.R. Ajward., dan D.B.P.H. Dissabandara. The Audit Expectations Gap and the Role of Audit Education: Evidence from Sri Lanka. Vidyodaya Journal of Management. 2017. 02(1):01-06.

Lestari, D.I., N. Maryani, dan A. Lestari. (2019), Pengaruh Due Professional Care Dan Kompetensi Auditor Terhadap Kualitas Audit. Jurnal Riset Akuntansi dan Keuangan. 7(2): 319-326.

Lee, T.H., A. Md. Ali., J.D. Gloeck., C.S. Yap., Y.L. Ng., and W. Boonyanet. (2010), The audit expectation gap in 
Thailand. Southern African Journal of Accountability and Auditing Research. 10:1-17.

Lee, T.H., J.D. Gloeck., and Palaniappan. (2007), The audit expectation gap: an empirical study in Malaysia. Southern African Journal of Accountability and Auditing Research. 7(1):1-15(15).

Masoud, N. (2017), An Empirical Study of Audit Expectation-performance Gap: The Case of Libya. Research in International Business and Finance. 4(12): 1-21.

Mirdah, A., G. Irianto, dan Yuliati. (2015), Analisis Fenomena Expectation Gap Dan Tanggung Jawab Hukum Auditor (Studi Pada P "MH \& N" di Jakarta). Iqtishadia. 8(2): 329-354.

Munidewi, I.A.B., dan I.D.A.E. Pertiwi. (2016), Menjembatani Fenomena Expectation Gap: Pemahaman Pengguna Laporan Keuangan dan Refleksi Diri Auditor. Jurnal Riset Akuntansi JUARA. 6(1): 32-45.

Okafor, C dan J.I. Otalor. (2013), Narrowing the Expectation Gap in Auditing: The Role of the Auditing Profession. Research Journal of Finance and Accounting. 4(2): 43-52.

Porter, B., C. Ó. hógartaigh, dan R. Basker-ville. (2012), Audit Expectation Performance Gap Revisited: Evidence from New Zealand and the United Kingdom, Part 1: The Gap in New Zealand and the United Kingdom in 2008. International Journal of Auditing. 16(2): 101-129.

Prayudi, M.A., G.A.K.R.S. Dewi, D.P. Vijaya, dan L.P. Ekawti. (2018), Teori Peran dan Konsep Expectation-Gap Fungsi Pengawasan Dalam Pengelolaan Keuangan Desa. Ekuitas Jurnal Ekonomi dan Keuangan. 2(4): 449-467.
Sari, N.P.P.F dan I.W. Ramantha. (2015), Pengaruh Sikap Skeptisme, Pengalaman Audit, Kompetensi, Dan Independensi Auditor Pada Kualitas Audit. E-Jurnal Akuntansi Universitas Udayana,11(2) : 470-482.

Regar, M.H. (2007), Mengenal Profesi Akuntan \& Memahami Laporannya. Bumi Aksara. Jakarta.

Sari, L.D.P., dan T. Widyastuti. (2018), Expectation Gap pada Persepsi Auditor Internal dengan Auditee terkait Kompetensi, Independensi, dan Kualitas $\mathrm{Au}$ dit. Jurnal Riset Akuntansi dan Perpajakan JRAP. 5(1): 53-64.

Suharsimi, A. (2013), Metodologi Penelitian Suatu Pendekatan Proposal. Rineka Cipta. Jakarta.

Sugiyono. (2012), Memahami Penelitian Kualitatif. Bandung: Alfabeta.

Syahyunan. (2015), Manajemen Keuangan 1. Edisi ketiga. USU Press. Medan.

Tandiontong, M. (2016), Kualitas Audit dan Pengukurannya. Alfabeta. Bandung.

Triandis, Harry C. (1971), Attitude and Attitude Change. John Willey \& Sons. Toronto.

Widosari, S.A dan Rahardja. (2012), Analisis Faktor-faktor Yang Berpengaruhi Terhadap Audit delay Pada Perusahaan Manufaktur Yang Terdaftar di BEI Tahun 2 Faktor-faktor Yang Mempengaruhi Audit delay Pada Perusahaan Manufaktur Yang Terdaftar di BEI Tahun 2008- 2010. Diponegoro Journal of Accounting. 1(1) : 1-13.

Yandi, D. F. (2015), Analisis Variabel-variabel Audit Expectation Gap atas Hasil Audit BPK (Studi Empiris Pada Pemerintahan Kota Jambi Tahun 2013). Jurnal Akuntansi \& Keuangan Unja. 1.1: 1-15. 